to show natural causation, where their constituents may be regarded as independently active. Limitations are imposed by organisation and by public opinion, but there are features of society which appear to be exempt from such limitations. These are (1) the hereditary endowment received by each generation, and (2) the individual reactions, though not the conditions, of what may be called the process of social promotion.

There is a presumption, Dr. Fisher said, that at the present day social promotion depends more on intellectual superiority and less on business aptitude than it did, say, a hundred years ago. Though no occupational class is strictly endogamous, the differences produced by selection for occupational status tend to be perpetuated. An unintentional feature that has arisen in our economic system is that the highest forms of ability are united with relative sterility, and vice versa. Whether a similar process was present in past civilisations it is for historians and archæologists to decide, but in regard to Great Britain " it is difficult to avoid the conclusion that a full half of whatever eugenic value this [fairly well-to-do] class contains may be counted as already lost". There is, Dr. Fisher concludes, no ground for fatalism ; but in considering the causes of an impending evil, we should as scientific workers distinguish between the inevitable and the avoidable, and as citizens we should in the latter case see to the application of the requisite control.

\section{Science and Philosophy}

IN his recent presidential address to the British Institute of Philosophy, under the title "Philosophy and the Ordinary Man", Sir Herbert Samuel pointed out that although all action and thought is the conscious or unconscious product of a philosophical attitude, the ordinary man takes little interest in philosophy, with which he thinks he has no coneern. In this respect philosophy contrasts strikingly with science, which arouses widespread interest. The reason is partly that expositors of science do not disdain to write in the vermacular, whereas many philosophers find it necessary to use a special terminology. It is chiefly, however, that science consists predominantly of a body of knowledge which commands common assent, whereas philosophy is largely an aggregate of individual systems of thought. Nevertheless, it has an important function to perform in constructing an authoritative code of morals for the guidance of those bewildered by the progress of science. It could best do this, said Sir Herbert, and at the same time command greater public interest, if it could be induced "to turn aside from a priori methods, to put no great faith in Logic as a guide, . . . and to press forward into the realms of metaphysics and ethics along the roads opened up by mathematics, physics, biology in general and psychology in particular, and by the social sciences".

The Principle of Causality

THE first principle which philosophy might receive, as established by science, is the principle of causality, which, in spite of recent attacks by some physicists, still reigns supreme. In support of this contention, Sir Herbert Samuel quoted a letter from Einstein and the published opinions of Planck. The principle of causality leads in philosophy straight to a theistic position; for since the universe is not self-explanatory, there must be "something else". We cannot, how. ever, at present fathom the nature of the Divine Mind. The principle of causality appears to deny human free-will, but although from a universal point of view this is so, events in the limited sphere of human action proceed as though our wills were free, and practical life must be conducted on that footing. A further application of the principle of causality in philosophy leads to a definition of the 'Good' as that which experience shows to promote well-being, rather than as an ideal standard of values. In the general adoption of the scientific method, philosophy will find its chief opportunity and its main strength.

\section{Harrison's Third Marine Timekeeper}

OF special interest among recent additions to the Science Museum collections is the third of the series of four chronometers designed and constructed by John Harrison between the years 1728 and 1759 ; this instrument has been lent by the Lords Commissioners of the Admiralty. The British Government had in 1714 offered an award of $£ 20,000$ for an accurate method of determining longitude at sea. It was realised that the problem could be solved by carrying on board ship a trustworthy timekeeper, and Harrison set himself the task of constructing such an instrument; after devoting practically his whole life to the work, he succeeded in winning the award with his fourth timekeeper. Harrison's No. 3 timekeeper is designed so as to be unaffected by the motion of a ship, while on account of the extensive use of friction wheels it requires no oiling ; it also embodies original and ingenious methods of compensation for variations of temperature and of arc. The chronometers Nos. 2 and 3 are now shown in motion side by side in the Science Museum; No. 4 is at the Royal Observatory, Greenwich.

\section{Zoological Collections of de Sélys}

MANY specialists on the systematics of the Vertebrata are under the mistaken impression that the famous collection made in the course of the nineteenth century by Michel Edmond de Sélys - Longchamps is either destroyed or lost. Happily this is not so. The collection was preserved in the Chateau de Longchamps près Waremme, Belgium, where it occupied the little museum which de Sélys built, but it was not readily accessible to specialists and was in the care of an old servitor. The fate of this collection, which is a veritable treasure-house for mammologists and ornithologists, has just been settled in a way which will give widespread pleasure. Barons Maurice, Raymond, and Edmond de Sélys-Longchamps, grandsons of the great zoologist, have given the whole collection to the nation, and it is being placed in the Royal Museum of Natural History at Brussels. Thus all de Sélys' zoological collections are brought together again, for in 1900 de Sélys bequeathed his important entomological collection to the Museum.

$$
\text { No. 3268, VoL. 129] }
$$

